\title{
PENENTUAN HARGA PRODUK KERAJINAN ROTAN BERBASIS AKTIVITAS
}

\author{
Ratih Ardia Sari ${ }^{1)}$, Ceria Farela Mada Tantrika ${ }^{2)}$, Rio Prasetyo Lukodono ${ }^{3)}$ \\ Sri Widiyawati ${ }^{4)}$ \\ 1),2),3,4)) Jurusan Teknik Industri, Universitas Brawijaya Malang
}

\begin{abstract}
Abstrak - Kerajinan rotan sintetis merupakan salah satu usaha kecil menengah yang berkembang di kota Malang. Produk dari kerajinan ini bervariasi mulai dari furniture (sofa, meja makan, kursi, meja) sampai pada kerajinan kecil (tempat air mineral, vas, tempat tisu) dengan berbagai bentuk dan warna. Inovasi produk sangat dibutuhkan agar usaha ini dapat bertahan dalam jangka waktu yang lama. Inovasi produk dimunculkan dari variasi produk. Variasi produk yang cukup banyak menjadikan usaha ini harus dapat menentukan harga pokok produksi setiap produknya agar dapat memperoleh laba yang terus meningkat. Penjualan produk ini cenderung mengalami kenaikan terutama pada musim liburan, tetapi saat ini profit yang didapatkan tidak sebanding dengan peningkatan penjualan. Hal ini mengindikasikan adanya kemungkinan ketidaktepatan penentuan harga pokok produksi. Selain itu, penentuan harga dihitung dengan menggunakan metode konvensional tanpa mempertimbangkan biaya overhead untuk masing-masing variasi produk. Oleh karena itu diperlukan perhitungan harga pokok produksi yang lebih sesuai dengan keadaan di dalam usaha kecil menengah ini. Penentuan harga pokok produksi dapat dilakukan berbasis aktivitas atau biasa disebut Activity-Based Costing (ABC). Cost driver dari usaha kerajinan rotan adalah waktu proses per unit barang (jam tenaga kerja / produk), luas lahan (m2), dan massa bahan baku utama plastik rotan $(\mathrm{kg})$. Cost pool dari usaha kerajinan ini adalah biaya listrik, biaya penyusutan fasilitas, biaya bahan baku penolong. Biaya listrik dihitung berdasarkan waktu proses per unit barang (jam/unit), biaya penyusutan fasilitas (luas lahan), dan biaya bahan baku penolong dihitung berdasarkan massa bahan baku utama plastik. Dari hasil penentuan harga dengan metode ABC didapatkan bahwa terdapat perbedaan harga sebesar 9\%. Penentuan harga pokok produksi saat ini lebih rendah dibandingkan dengan harga pokok produksi metode ABC. Laba yang diperkirakan oleh usaha ini lebih besar dibandingkan dengan laba metode $\mathrm{ABC}$ yang lebih realistis. Terdapat beberapa produk yang penentuan harga produksinya lebih rendah bila dibandingkan dengan biaya yang dikeluarkan untuk produksi.
\end{abstract}

Kata Kunci: Cost Driver, Harga Pokok Produksi, Kerajinan Rotan Sintetis, Metode Activity Based Costing

Sektor usaha kecil menengah (UKM) memiliki peranan yang penting dalama mendorong pertumbuhan perekonomian bangsa Indonesia. Untuk menjaga keberlangsungan hidup UKM diperlukan pertumbuhan serta peningkatan profitabilitas dari waktu ke waktu. Profitabilitas yang meningkat salah satu caranya dapat dilakukan dengan penentuan harga produk yang tepat. Ketidaktepatan dalam penentuan harga pokok produksi berakibat pada kerugian suatu usaha karena harga pokok produksi dapat sebagai dasar untuk menetapkan harga jual dan laba serta sebagai alat untuk mengukur efisiensi pelaksanaan proses produksi serta sebagai dasar untuk pengambilan keputusan bagi pemilik usaha. Oleh karena itu penentuan harga pokok harus dihitung dengan cermat.
Penentuan harga pokok produksi dapat dilakukan berbasis aktivitas atau biasa disebut Activity-Based Costing (ABC). Dalam metode ini perhitungan biaya overhead pabrik dilakukan lebih akurat dan relevan [1], [2]. Pada metode ini, seluruh biaya tidak langsung dikelompokkan sesuai dengan aktivitas masing-masing, kemudian masing-masing kelompok biaya (cost pool) tersebut dihubungkan dengan masing-masing aktivitas dan dialokasikan berdasar aktivitasnya masingmasing [3]. Dasar alokasi yang digunakan adalah jumlah aktivitas dalam setiap cost pool tersebut. Metode ini menggunakan jenis pemicu biaya yang lebih banyak sehingga dapat mengukur sumber daya yang digunakan oleh produk secara lebih akurat [4], [5].

Sentra usaha kecil rotan di kota Malang merupakan salah satu industri kerajinan yang 
dahulunya pernah berjaya. Namun seiring dengan waktu, usaha ini mulai mengalami penurunan karena ketersediaan rotan serta melambungnya harga rotan. Harga rotan yang terus melambung membuat banyak pelaku usaha kecil ini gulung tikar. Oleh karena itu ada beberapa pemilik usaha mencoba mengganti bahan baku rotan menjadi rotan sintetik. Anyaman rotan sintesis ini bervariasi mulai dari furniture (sofa, meja makan, kursi, meja) sampai pada kerajinan kecil (tempat air mineral, vas, tempat tisu) dengan berbagai bentuk dan warna. Inovasi produk sangat dibutuhkan agar usaha ini dapat bertahan dalam jangka waktu yang lama. Dengan inovasi produk maka usaha ini menghasilkan beberapa variasi produk. Variasi produk yang cukup banyak menjadikan usaha ini harus dapat menentukan harga pokok produksi setiap produknya agar dapat memperoleh laba yang terus meningkat. Produk ini dijual baik di wilayah Malang, Madiun bahkan Solo. Penjualan produk cenderung mengalami kenaikan terutama pada musim liburan, tetapi saat ini profit yang didapatkan tidak sebanding dengan peningkatan penjualan. Hal ini mengindikasikan adanya kemungkinan ketidaktepatan penentuan harga pokok produksi. Selain itu, penentuan harga dihitung dengan menggunakan metode konvensional tanpa mempertimbangkan biaya overhead untuk masing-masing variasi produk. Penentuan harga produk ditentukan berdasarkan biaya bahan baku, biaya upah tenaga kerja dan biaya overhead yang dibagi rata antar variasi produk serta tidak mempertimbangkan laporan biaya. Oleh karena iu diperlukan perhitungan harga pokok produksi yang lebih sesuai dengan keadaan di dalam usaha kecil menengah ini.

Penelitian ini bertujuan untuk menentukan cost driver, mengklasifikasikan biaya berdasarkan cost driver, mengalokasikan biaya pada produk dan menghitung harga pokok produksi, serta menetapkan harga produk. Dengan adanya penelitian ini diharapkan mampu membantu industry kecil rotan dalam menentukan harga pokok produksi dan harga jual produknya sehingga profitabilitasnya dapat dipertahankan.

\section{METODE}

Pada penelitian ini akan ditentukan harag pokok produksi produk kerajinan dengan menggunakan metode ABC. Data yang dibutuhkan dalam penelitian ini meliputi Aliran proses dan aktivitas, waktu proses, jenis produk dan banyaknya yang diproduksi, jenis dan banyaknya material, jenis dan banyaknya sumber daya, biaya material, tenaga kerja, dan overhead. Dari data yang diperoleh maka akan dilakukan pengolahan data melalui beberapa langkah yaitu pmbuatan peta proses, perhitungan waktu aktivitas, penentuan cost driver, alokasi biaya overhead terhadap produk, perhitungan HPP, dan penentuan harga produk. Selanjutnya tahap akhir yang dilakukan adalah analisa dan kesimpulan saran.

\section{HASIL DAN PEMBAHASAN}

Secara garis besar produk yang dihasilkan dapat dibedakan menjadi 2 yaitu produk yaitu kerajian asesoris seperti tempat air mineral, tempat tisu dan produk furniture seperti kursi ayak, kursi bonevuille dll. Proses pembuatan produk kerajinan rotan sangat tergantung pada kreasi, imajinasi, dan keterampilan pembuatnya, yang merupakan gabungan dari proses mekanik (pemotongan dan pengolahan rotan) dan pengerjaan seni tradisional (pembentukan produk jadi secara manual). Tahapan awal proses produksi untuk produk kerajinan baik asesoris maupun furnitur secara umum adalah persiapan bahan baku mulai dari rattan syntetic, bahan penolong, bahan tambahan dan kerangka. Kerangka disesuaikan dengan model yang diinginkan oleh pelanggan ataupun pemilik usaha. Tahapan selanjutnya adalah menganyam produk yang dilakukan secara manual oleh pekerja. Pengayaman dilakukan dengan mengatur pola rattan syntetis pada pola yang diinginkan. Setelah diatur pola, maka untuk menjaga agar pola tetap terjaga dilakukan pemberian paku (bahan baku penolong). Penganyaman memiliki waktu proses yang berbeda untuk tiap bentuk anyaman dan tiap bentuk produk. Tahapan terakhir dalam proses produksi adalah memberikan fitur tambahan dan finishing.

Setiap produk membutuhkan presentase bahan baku yang relative berbeda. Bahan baku kerangka dan plastic dihitung berdasarkan beratnya. Biaya material untuk produk dihitung berdasarkan berat produk tersebut. Biaya tenaga kerja dihitung berdasarkan hasil kerja (output) yang dihasilkan Tabel 1 
menunjukan persentase berat bahan baku yang diperlukan untuk beberapa produk yang diproduksi, biaya tenaga kerja serta waktu proses untuk beberapa jenis produk

Tabel 1. Presentase Berat Material

\begin{tabular}{|c|l|c|c|c|c|}
\hline No & \multicolumn{1}{|c|}{ Nama Barang } & $\begin{array}{c}\text { Alumunium / } \\
\mathrm{kg}\end{array}$ & Rotan Sintetik/kg & Biaya Tenaga Kerja & $\begin{array}{c}\text { Waktu } \\
\text { Proses }\end{array}$ \\
\hline 1 & Kursi A & 2.1 & 2.38 & $\mathrm{Rp} 90.000$ & 7.2 \\
\hline 2 & Kursi B & 2.4 & 3.5 & $\mathrm{Rp} 140.000$ & 11.2 \\
\hline 3 & Kursi C & 4.2 & 3.75 & $\mathrm{Rp} \mathrm{200.000}$ & 16.0 \\
\hline 4 & Kursi D & 4.5 & 6.75 & $\mathrm{Rp} \mathrm{220.000}$ & 17.6 \\
\hline 5 & Meja A & 1.92 & 2.25 & $\mathrm{Rp} 120.000$ & 9.6 \\
\hline 6 & Kursi E & 2 & 1.56 & $\mathrm{Rp} \mathrm{70.000}$ & 5.6 \\
\hline 7 & Meja B & 1.92 & 1.8 & $\mathrm{Rp} \mathrm{70.000}$ & 5.6 \\
\hline
\end{tabular}

Pengayaman dilakukan dengan persiapan kerangka dari tukang las yang menjadi supplier usaha ini serta rattan sintetik yang diperoleh dari pabrik. Pengayaman dilakukan dengan mengatur pola pada kerangka dan setelah didapatkan pola dilakukan penguncian pola menggunakan paku yang dilakukan berulang kali sampai didapatkan produk yang diinginkan. Untuk produk yang memiliki desain tertentu kadangkala menggunakan fitur tambahan yang akan dipasang setelah maupun pada saat pengayaman.

Selama ini penentuan harga pokok produksi ditentukan dari harga material (kerangka dan rattan plastik), harga bahan baku penolong dan biaya tenaga kerja. Harga jual didapatkan dari harga pokok produksi ditambahkan dengan laba yang diinginkan. Penawaran harga dapat mempengaruhi laba yang diperoleh. Dengan laba yang saat ini didapatkan, pemilik usaha merasa memiliki banyak keuntungan dari produk yang dibuat. Padahal biaya overhead seperti biaya listrik, air, biaya penyusutan, biaya bahan penolong belum dipertimbangkan. Biaya overhead dalam activity based costing dipecah berdasarkan cost drivernya untuk menentukan atau membebankan biaya overhead pada produk. Dengan banyaknya variasi produk membuat penggunaan biaya overhead yang berbeda. Oleh karena itu dari tiap-tiap biaya overhead ditentukan cost drivernya. Tabel 2 menunjukkan biaya overhead dengan cost driver tarifnya.

Tabel 2. Biaya Overhead dan Cost Drivernya

\begin{tabular}{|c|c|c|}
\hline No & Biaya Overhead & Cost Driver Tarif \\
\hline 1 & Listrik & Jam Tenaga Kerja \\
\hline 2 & Penyusutan & Luas Lahan \\
\hline 3 & Bahan Baku Penolong & Massa Bahan Baku Utama \\
\hline
\end{tabular}

Biaya overhead pada industri kerajinan ini terdiri dari biaya listrik dan air, penyusutan gedung dan bahan baku penolong. Untuk menghitung beban biaya overhead untuk masing-masing produk ditentukan berdasarkan tarif listrik dan air per jamnya. Tarif ini ditentukan dengan menghitung penggunaan biaya listrik dan air selama setahun. Untuk menentukan tarif Rupiah per jam dari produk maka dilakukan pembagian antara total biaya listrik dan air dengan jumlah jam tenaga kerja selama setahun. Tarif untuk biaya listrik dan air adalah Rp 1. 607, 00 per jamnya. Sehingga untuk tarif beban listrik yang dibebankan kepada produk didapatkan dari tarif beban biaya listrik dan air per jam dikalikan dengan waktu proses produk.

Selain biaya listrik dan air, biaya overhead lain didapatkan dari aset yan dimiliki yaitu rumah atau gedung yang digunakan untuk tempat produksi. Lokasi industri ini berada di lahan seluas $100 \mathrm{~m} 2$,. Nilai bangunan sesuai yang tertera pada PBB adalah sebesar Rp 150.000.000,00. Penyusutan aset dilakukan dengan metode straight line depresiation dimana penyusutan per tahunnya didapatkan 
dari nilai jual bangunan dibagi dengan lama pemakaian. Lama pemakaian diperkirakan selama 25 tahun. Sehingga penyusutan sebesar $\operatorname{Rp} 150.000 .000,00 /(25$ tahun $x 12$ bulan $)=$ Rp 500.000,00. Lahan produksi sebesar $40 \mathrm{~m} 2$ dari total lahan sebesar $100 \mathrm{~m} 2$. Sehingga penyusutan per bulan didapatkan dari $40 \mathrm{~m} 2 /$ $100 \mathrm{~m} 2$ x Rp. $500.000,00=$ Rp. $200.000,00$.

Dalam satu bulan industri kerajinan ini dapat menghasilkan rata-rata 35 produk baik untuk produk furnitur maupun kerajianan. Beban penyusutan per produk didapatkan dari waktu proses per produk dibagi dengan total jam kerja dikalikan dengan biaya penyusutan per bulan sebasar Rp. 200.000,00. Beban penyusutan untuk produk bervariasi bergantung pada jenis dan lama pengerjaan produk. Tabel 3 menunjukkan beban biaya listrik di masing-masing produk serta biaya penyusutan.

Tabel 3. Biaya Listrik dan Air serta Beban Penyusutan Per Produk

\begin{tabular}{|c|c|c|c|c|c|c|c|c|}
\hline \multirow{2}{*}{$\begin{array}{l}\text { No } \\
\\
1\end{array}$} & Nama Barang & \multirow{2}{*}{$\begin{array}{c}\text { Waktu } \\
\text { proses } \\
7.2\end{array}$} & \multicolumn{2}{|c|}{$\begin{array}{l}\text { Beban biaya } \\
\text { listrik dan air }\end{array}$} & \multirow{2}{*}{$\begin{array}{c}\text { Jumlah } \\
6\end{array}$} & \multirow{2}{*}{$\begin{array}{c}\text { Total } \\
\text { Waktu } \\
43.2\end{array}$} & \multicolumn{2}{|c|}{$\begin{array}{c}\text { Beban } \\
\text { Penyusutan Per } \\
\text { Produk Per } \\
\text { Bulan } \\
\end{array}$} \\
\hline & Kursi A & & $\mathrm{Rp}$ & 11.571 & & & $\mathrm{Rp}$ & 7.339 \\
\hline 2 & Kursi B & 11.2 & $\mathrm{Rp}$ & 18.000 & 2 & 22.4 & $\mathrm{Rp}$ & 11.417 \\
\hline 3 & Kursi C & 16.0 & $\mathrm{Rp}$ & 25.714 & 1 & 16.0 & $\mathrm{Rp}$ & 16.310 \\
\hline 4 & Kursi D & 17.6 & $\mathrm{Rp}$ & 28.286 & 2 & 35.2 & $\mathrm{Rp}$ & 17.941 \\
\hline 5 & Meja A & 9.6 & $\mathrm{Rp}$ & 15.429 & 1 & 9.6 & $\mathrm{Rp}$ & 9.786 \\
\hline 6 & Kursi E & 5.6 & $\mathrm{Rp}$ & 9.000 & 0 & 0.0 & $\mathrm{Rp}$ & 5.708 \\
\hline 7 & Meja B & 5.6 & $\mathrm{Rp}$ & 9.000 & 2 & 11.2 & $\mathrm{Rp}$ & 5.708 \\
\hline 8 & Meja C & 13.6 & $\mathrm{Rp}$ & 21.857 & 1 & 13.6 & $\mathrm{Rp}$ & 13.863 \\
\hline 9 & Kursi E & 5.6 & $\mathrm{Rp}$ & 9.000 & 0 & 0.0 & $\mathrm{Rp}$ & 5.708 \\
\hline 10 & Sketsel & 5.8 & $\mathrm{Rp}$ & 9.321 & 0 & 0.0 & $\mathrm{Rp}$ & 5.912 \\
\hline 11 & Tempat air mineral A & 2.1 & $\mathrm{Rp}$ & 3.444 & 5 & 10.7 & $\mathrm{Rp}$ & 2.184 \\
\hline 12 & Tempat tissue $\mathrm{A}$ & 2.0 & $\mathrm{Rp}$ & 3.214 & 5 & 10.0 & $\mathrm{Rp}$ & 2.039 \\
\hline & Total Jam & & & & & 196.2 & & \\
\hline
\end{tabular}

Selain biaya listrik air dan penyusutan, biaya overhead dari usaha kecil ini adalah penggunaan bahan baku penolong. Tabel 4 menunjukkan penggunaan bahan plastik rattan syntetis dan juga biaya overhead untuk bahan baku penolong. Setelah didapatkan proporsi dari biaya overhead dari biaya listrik, biaya penyusutan dan biaya bahan baku penolong, maka dapat dihitung biaya overhead untuk masing-masing produk. Tabel 5 menunjukkan alokasi biaya overhead tiap produk.

Perhitungan harga pokok produksi (HPP) dilakukan dengan menambahkan biaya bahan baku, biaya tenaga kerja dan biaya overhead. Penentuan harga produk didapatkan dengan menjumlahkan harga pokok produksi dengan biaya administrasi , biaya pemasaran dan laba yang diinginkan. Dari hasil harga pokok produksi yang didapatkan dengan metode yang diterapkan usaha ini, dapat dibandingkan perbedaannya. Perbedaan mencolok terlihat dari biaya overhead yang tidak dipertimbangkan dalam penentuan harga pokok produksi seperti pada tabel 6 .

Selama ini pemilik mengira laba yang diperolehnya cukup tinggi untuk produk yang diproduksinya. Tetapi berdasarkan metode $\mathrm{ABC}$ didapatkan hasil bahwa ada beberapa produk yang harga jualnya mendekati harga pokok produksi. Hal ini mengindikasikan bahwa ada beberapa produk yang harga jual di konsumen lebih rendah dibandingkan dengan biaya yang dikeluarkan untuk memproduksi barang tersebut karena harga pokok produksi belum ditambahkan dengan biaya administrasi dan biaya pemasaran. Tabel 6 menunjukkan perbandingan laba yang diperoleh dari metode yang diterapkan usaha ini dengan metode $\mathrm{ABC}$ yang diusulkan. Untuk semua produk yang dijual, rata-rata laba yang dihitung berdasarkan metode penentuan harga pokok produksi yang dilakukan saat ini didapatkan sekitar $27.7 \%$.

Tabel 4. Kebutuhan dan Biaya Bahan Baku Penolong Per Produk 


\begin{tabular}{|c|c|c|c|c|c|}
\hline No & Nama Barang & $\begin{array}{c}\text { Rotan } \\
\text { Sintetik/kg }\end{array}$ & Jumlah & Total Rotan & $\begin{array}{c}\text { Biaya Bahan Baku penolong } \\
\text { per produk }\end{array}$ \\
\hline 1 & Kursi A & 2.38 & 6 & 14.28 & Rp 5.683 \\
\hline 2 & Kursi B & 3.5 & 2 & 7 & $\mathrm{Rp} 8.358$ \\
\hline 3 & Kursi C & 3.75 & $\frac{2}{1}$ & 3.75 & Rp 8.955 \\
\hline 4 & Kursi D & 6.75 & 2 & 13.5 & Rp 16.118 \\
\hline 5 & Meja A & 2.25 & 1 & 2.25 & $\operatorname{Rp} 5.373$ \\
\hline 6 & Kursi E & 1.56 & 0 & 0 & Rp 3.725 \\
\hline 7 & Meja B & 1.8 & 2 & 3.6 & $\operatorname{Rp} 4.298$ \\
\hline 8 & Meja C & 3.75 & 1 & 3.75 & $\operatorname{Rp} 8.955$ \\
\hline 9 & Kursi E & 0.08 & 0 & 0 & $\begin{array}{ll}\mathrm{Rp} & 179\end{array}$ \\
\hline 10 & Sketsel & 1.88 & 0 & 0 & Rp 4.489 \\
\hline 11 & Tempat air mineral A & 0.63 & 5 & 3.13 & $\mathrm{Rp} \quad 1.492$ \\
\hline 12 & Tempat tissue $\mathrm{A}$ & 0.31 & 5 & 1.56 & $\begin{array}{ll}\mathrm{Rp} & 746\end{array}$ \\
\hline 13 & Toples A & 0.63 & 0 & 0 & $\begin{array}{ll}\mathrm{Rp} & 1.492\end{array}$ \\
\hline 14 & Tempat buah A & 0.63 & 0 & 0 & $\begin{array}{ll}\mathrm{Rp} & 1.492\end{array}$ \\
\hline 15 & Tempat payung A & 1 & 5 & 5 & $\operatorname{Rp} 2.388$ \\
\hline 16 & Tempat majalah A & 1 & 5 & 5 & $\operatorname{Rp} 2.388$ \\
\hline 17 & Tempat buah B & 1.25 & 0 & 0 & $\operatorname{Rp} 2.985$ \\
\hline 18 & Tempat payung B & 1.25 & 0 & 0 & $\operatorname{Rp} 2.985$ \\
\hline & Total Jam & & & 62.818 & \\
\hline
\end{tabular}

Tabel 5. Alokasi Biaya Overhead Tiap Produk

\begin{tabular}{|c|c|c|c|c|c|}
\hline No & Nama Barang & $\begin{array}{c}\text { Biaya } \\
\text { Listrik dan } \\
\text { Air }\end{array}$ & $\begin{array}{c}\text { Biaya } \\
\text { Penyusutan }\end{array}$ & $\begin{array}{l}\text { Biaya Bahan Baku } \\
\text { penolong }\end{array}$ & $\begin{array}{c}\text { Total Biaya } \\
\text { Overhead }\end{array}$ \\
\hline 1 & Kursi A & $\begin{array}{ll}\mathrm{Rp} & 11.571\end{array}$ & Rp 7.339 & $\begin{array}{ll}\mathrm{Rp} & 5.683 \\
\end{array}$ & Rp 24.594 \\
\hline 2 & Kursi B & $\begin{array}{ll}\mathrm{Rp} & 18.000\end{array}$ & $\operatorname{Rp} 11.417$ & $\begin{array}{ll}\mathrm{Rp} & 8.358\end{array}$ & Rp 37.774 \\
\hline 3 & Kursi C & Rp 25.714 & Rp 16.310 & Rp 8.955 & Rp 50.979 \\
\hline 4 & Kursi D & $\begin{array}{ll}\mathrm{Rp} & 28.286\end{array}$ & Rp 17.941 & $\begin{array}{ll}\mathrm{Rp} & 16.118\end{array}$ & $\begin{array}{ll}\mathrm{Rp} & 62.345\end{array}$ \\
\hline 5 & Meja A & $\begin{array}{ll}\mathrm{Rp} & 15.429 \\
\end{array}$ & Rp 9.786 & 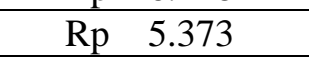 & Rp 30.587 \\
\hline 6 & Kursi E & Rp $\quad 9.000$ & Rp 5.708 & Rp 3.725 & Rp 18.434 \\
\hline 7 & Meja B & $\begin{array}{ll}\mathrm{Rp} & 9.000 \\
\end{array}$ & $\begin{array}{ll}\mathrm{Rp} & 5.708 \\
\end{array}$ & Rp 4.298 & Rp 19.007 \\
\hline
\end{tabular}

Terdapat perbedaan sekitar 9\% lebih tinggi dibandingan dengan metode $\mathrm{ABC}$ yang diusulkan. Laba yang diperoleh oleh metode $\mathrm{ABC}$ lebih rendah bila dibandingkan dengan metode yang diterapkan oleh perusahaan. Dari tabel juga dapat dilihat bahwa terdapat produk yang malah rugi apabila ditetapkan dengan harga jual saat ini seperti produk meja A dan tempat tisu A. Dari hasil perhitungan dapat disimpulkan bahwa dengan metode $\mathrm{ABC}$, penentuan harga pokok produksi dapat ditentukan berdasarkan aktivitas. Terdapat beberapa produk yang harus disesuaikan dengan harga pokok produksi untuk mendapatkan laba yang lebih tinggi. Dari beberapa barang yang diproduksi, terdapat produk yang harga jualnya lebih rendah apabila dibandingkan dengan harga pokok produksi berdasarkan aktivitas yang dilakukan untuk memproduksi produk tersebut. Oleh karena metode $\mathrm{ABC}$ dapat digunakan untuk penentuan harga jual produk sehingga lebih realistis dan lebih relevan.

Tabel 6. Perbandingan Laba Metode ABC dan Konvensional

\begin{tabular}{|c|l|c|c|c|c|}
\hline \multirow{2}{*}{ No } & \multirow{2}{*}{ Nama barang } & \multirow{2}{*}{ Harga Jual } & \multicolumn{2}{|c|}{ \% Laba } & \multirow{2}{*}{ Perbedaan Laba } \\
\cline { 4 - 5 } & & & Konvensional & ABC & \\
\hline 1 & Kursi A & $\mathrm{Rp} 765.000$ & $33.22 \%$ & $29.57 \%$ & $3.65 \%$ \\
\hline 2 & Kursi B & $\mathrm{Rp} 1.035 .000$ & $32.35 \%$ & $29.20 \%$ & $3.15 \%$ \\
\hline
\end{tabular}




\begin{tabular}{|c|c|c|c|c|c|}
\hline 3 & Kursi C & $\mathrm{Rp} 1.215 .000$ & $20.62 \%$ & $17.00 \%$ & $3.62 \%$ \\
\hline 4 & Kursi D & Rp 1.665.000 & $21.56 \%$ & $19.53 \%$ & $2.03 \%$ \\
\hline 5 & Meja A & $\mathrm{Rp} \quad 675.000$ & $24.34 \%$ & $1.47 \%$ & $22.87 \%$ \\
\hline 6 & Kursi E & $\mathrm{Rp} \quad 607.500$ & $34.91 \%$ & $29.41 \%$ & $5.50 \%$ \\
\hline 7 & Meja B & $\begin{array}{ll}\mathrm{Rp} & 630.000 \\
\end{array}$ & $22.79 \%$ & $10.63 \%$ & $12.15 \%$ \\
\hline 8 & Meja C & $\mathrm{Rp} 1.125 .000$ & $24.93 \%$ & $12.70 \%$ & $12.24 \%$ \\
\hline 9 & Kursi E & $\begin{array}{ll}\mathrm{Rp} & 607.500 \\
\end{array}$ & $57.65 \%$ & $51.92 \%$ & $5.73 \%$ \\
\hline 10 & Sketsel & 765.000 & $25.98 \%$ & $26.61 \%$ & $-0.63 \%$ \\
\hline 11 & Tempat air mineral $\mathrm{A}$ & 157.500 & $28.10 \%$ & $13.45 \%$ & $14.65 \%$ \\
\hline 12 & Tempat tissue $\mathrm{A}$ & 108.000 & $25.58 \%$ & $3.80 \%$ & $21.78 \%$ \\
\hline 13 & Toples A & 157.500 & $26.51 \%$ & $11.62 \%$ & $14.89 \%$ \\
\hline 14 & Tempat buah A & $\mathrm{Rp} \quad 180.000$ & $29.86 \%$ & $25.86 \%$ & $4.00 \%$ \\
\hline 15 & Tempat payung A & $\mathrm{Rp} \quad 202.500$ & $23.60 \%$ & $12.95 \%$ & $10.65 \%$ \\
\hline 16 & Tempat majalah A & $\begin{array}{ll}\mathrm{Rp} & 202.500 \\
\end{array}$ & $23.60 \%$ & $12.95 \%$ & $10.65 \%$ \\
\hline 17 & Tempat buah B & $\begin{array}{ll}\mathrm{Rp} & 247.500 \\
\end{array}$ & $24.65 \%$ & $15.96 \%$ & $8.68 \%$ \\
\hline 18 & Tempat payung $\mathrm{B}$ & 337.500 & $19.56 \%$ & $12.30 \%$ & $7.26 \%$ \\
\hline \multicolumn{3}{|c|}{ Rata-rata } & $27.77 \%$ & $18.72 \%$ & $9.05 \%$ \\
\hline
\end{tabular}

\section{KESIMPULAN DAN SARAN \\ Kesimpulan}

Kesimpulan yang dapat diambil dari penelitian ini adalah cost driver dari usaha kerajinan rotan adalah waktu proses per unit barang (jam tenaga kerja / produk), luas lahan (m2), dan massa bahan baku utama plastik rotan $(\mathrm{kg})$. Sedangkan cost pool dari usaha kerajinan ini adalah biaya listrik, biaya penyusutan fasilitas, biaya bahan baku penolong. Biaya dapat diklasifikasikan pada level unit barang untuk biaya listrik, sedangkan klasifikasi biaya penyusutan fasilitas dilakukan pada level facility. Biaya listrik dihitung berdasarkan waktu proses per unit barang (jam/unit), biaya penyusutan fasilitas ( luas lahan), dan biaya bahan baku penolong dihitung berdasarkan massa bahan baku utama plastik. Dari hasil perbandingan bahwa penentuan harga pokok produksi saat ini lebih rendah dibandingkan dengan harga pokok produksi metode ABC. Laba yang diperkirakan oleh pemilik lebih besar dibandingkan dengan laba metode $\mathrm{ABC}$ yang lebih realistis. Pemilik usaha merasa usahanya memiliki banyak keuntungan padahal ada beberapa produk yang penentuan harga jualnya lebih rendah bila dibandingkan dengan biaya yang dikeluarkan untuk produksi. Berdasarkan penelitian yang telah dilakukan saran yang dapat diberikan untuk penelitian selanjutnya adalah penelitian terkait Activity Based Management untuk mengefisienkan proses produksi karena harga jual produk relatif bersaing dengan pasar dan penelitian untuk membuat sistem informasi yang dapat membantu pemilik usaha menentukan harga pokok produksi dengan mudah dan cepat yang mempertimbangkan aktivitas produksi.

\section{DAFTAR PUSTAKA}

[1]. Carter dan Usry. 2005. Akuntansi Biaya, Edisi 13 buku 2. Jakarta: Salemba Empat.

[2]. Connolly, T. and G. Ashworth. 1994. An Integrated Activity-Based Approach to Budgeting. Management Accounting, 77:3, 32-37

[3]. Fees, Reeve, Warren, 2005. Pengantar Akuntansi, Edisi 21, Penerbit Salemba Empat, Jakarta.

[4]. Garrison, Ray H,. 1991. Manajerial Accounting : Concepts for Planning, Control, and Decision, Richard D Irwin Inc.

[5]. Barfield, Raiborn dan Kinney. 2001. Cost Accounting: Traditions and Innovations 4th Edition.: South-Western Pub 1 